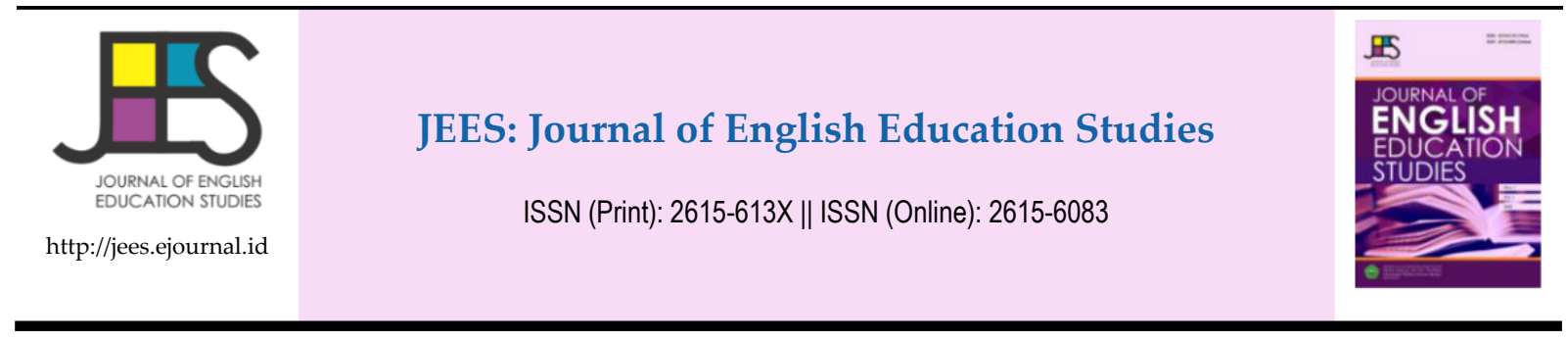

\title{
The Development of English Teaching Material Base Local Wisdom at SMKN 1 Cinangka
}

\section{Sisca Wulansari Saputri ${ }^{1}$, Ina Rohiyatussakinah ${ }^{2}$}

${ }^{1}$ English Education Study Program of Teacher Training and Education Faculty, Universitas Banten Jaya

2 English Education Study Program of Teacher Training and Education Faculty, Universitas Banten Jaya

\section{${ }_{3}$ ARTICLE INFO}

Keywords:

Teaching Material

Development

Local Wisdom

\section{ABSTRACT}

This research aims to know the development result score of students using module which content local wisdom at SMKN 1 Cinangka. Teaching material in this research is module. This research method that uses is R\&D method. This research uses 10 students with small group trial and 30 students with limited field trial. The researcher used technique of collecting data, such as; observation, interview, questionnaire and test. The result indicated that: after getting learning by using local wisdom module, there is any increasing for the score. The average score for experiment class is 54 become 81.5 , and for control class is 48.5 and 63.5. It means that learning using local wisdom module got increasing score for experimental and control class.

This is an open access article distributed under the terms of the Creative Commons Attribution 4.0 International License, which permits unrestricted use, distribution, and reproduction in any medium, provided the original work is properly cited. (c) 2019 Sisca Wulansari Saputri, Ina Rohiyatussakinah

\section{INTRODUCTION}

Any some procedure that needed in developing module, those are goal/purpose, clear learning and clear content. Based on Parmin (2012), "any some criteria in module development, they are; to help students in preparing independent learning, to have learning activity plan that can be responded maximal, to load complete learning content and able to give learning chance to the students, can monitor student's learning activity, and can give suggestion, instructions and information for improving student's learning". "Model and theory of learning should be shown with three components, they are; learning condition, learning method, and learning result" (Parmin, 2012). The material that developed in teaching material is module that content about local wisdom.

\footnotetext{
${ }^{1}$ Corresponding author's address: English Education Study Program of Teacher Training and Education Faculty, Universitas Banten Jaya, Banten, Indonesia e-mail: siscawulansari.saputri@gmail.com 2 Corresponding author's address: English Education Study Program of Teacher Training and Education Faculty, Universitas Banten Jaya, Banten, Indonesia e-mail:
inarohiyatussakinah@gmail.com
} 
The problem in this research is not reached yet the maximum result, because the students were doing practice field. To make maximum result, the researcher also gets supported by interview with English teacher at SMKN 1 Cinangka. In this moment, module that used at SMKN 1 Cinagka especially for grade XI still commonly. Books or modules that should be used for vocational high schools on the coast can raise issues around them. Therefore, the researcher feels that there must be a change to the companion book(module).

According to Sibrani (2012) "the comprehension about local wisdom concept is needed, it was being managing social life". One of local wisdom's functions is how to form young generation's characters as socio cultural. So they are being aware with local culture. The way that can be given from them by integrating local culture with the values in learning process, in this case is the using of learning module.

Pannen in Prastowo (2012:26) "teaching material is the arranged material systematically, used by teacher and student in learning process". Sanjaya (2010) defines that "learning material is anything that is curriculum content that should be mastered by students and base competency in achieving competency standard of every subjects in certain education unit". It is agreed by Prastowo (2012) concluding that "teaching material is anything (information, material, and text) arranged systematically, putting complete thing of competency that will be mastered by students and used in learning process by aiming planning and research of learning implementation such as textbook, module, handout, worksheet, audio teaching material, integrative teaching material and etc". Based on the definitions above, it can be concluded that teaching material is a set of teaching material (information, material, and text) arranged systematically and used in learning. "Teaching material is the smallest program of teaching learning, learnt by students individually or thought to student themselves (self-instructional)" (Winkel, 2009). National Education Department (2002) defines that "teaching material is a unit of leaning material presented in self-instruction form, it means that learning material arranged in module can be learnt by students independently by limited help from teacher or the other people". So, it can concluded that teaching material isthe smallest program of teaching learning and planned that is learnt by students individually because teaching material a unit that stands alone and consist of a series of learning activity arranged to help students to gain their goal formulated specifically and clearly.

\section{Module}

Ashyar (2012) defines that "module is as printed based one of teaching material forms arranged for learning independently by students, therefore module is completed with instruction for learning individually. Students can learn by themselves without teacher directly". Hamdani (2011) defines "module is tool of learning that consist of material, method, limitation of learning material, learning activity instruction, exercise and evaluation way arranged systematically and attractively to gain hoped competency and can be used independently."

National Education Department in the book Learning Technique with Module (Teknik Belajar dengan Modul) (2002) defines that "module is as a unit of learning material presented in form of "self-instruction". It means learning material arranged in the module can be learnt by students independently with limited help from teacher and the other people, so it can concluded that module is a smallest and planned program of learning teaching that is learnt by student individually, because module is a unite that stands alone and consist of a series leaning activity arranged to help students to gain amount of aim formulated specially and clearly. Next, module learning is stated by Kurmiasih \& Sani (2014) that "an independent learning process about a unit of certain discussion by using teaching material arranged systematically, operationally and directed to be used by students, and by using guidance for teacher". Module can be formulated as complete unit that stands alone and consists of a series of learning activity arranged to help students to gain the aim formulated specially and clearly. 
Based on the definition above, it can be concluded that module is teaching material arranged systematically that consists of material, method, border of learning material, learning activity instructions, exercise and evaluation ways that can be used by students independently. By module, students can learn themselves and not depend on the others. Attitude is opinion organisation, someone's belief about giving basic to someone to respond or have attitude in certain way. "Attitude is mental readiness that takes place in one's self with the experience, give direction and decide respond to various objects and situations" (Allport in Sarwono and Eko, 2009). Attitude contains three components that form attitude structure. Three components are presented as follows:

1) Cognitive component (perceptual component), is the component related to science, views, belief. This component relates to how someone has perception of attitude object.

2) Affective component (emotional component), is the component related to happiness or unhappiness of attitude object. Happiness is positive thing while unhappiness is negative thing. This component shows positive and negative attitude.

3) Conative component (behaviour component) is the component that tends to act to attitude of object. This component shows intensity of attitude to show how big and small tendency in acting or having attitude to attitude of object.

\section{The Definition of Local Wisdom}

Local wisdom can be comprehended as human's effort by using his cognitive to act and has attitude to an object or event in certain room. (in Ridwan, 2007) the definition is arranged "etymologically where wisdom is understood as someone's ability in using his mind in acting and having attitude as assessment result to an object or happened event". The concept of local wisdomby Dahliani \& Ispurwono (in International Journal of Education and Research Vol. 3 No. 6 June (2015: 158) as follows: "The concept of local wisdom in environmental management was described by Berkes (1993) with the terminology of traditional ecological knowledge. The term means a collection of knowledge, practices and beliefs that evolved through adaptive process (adjustment) passed from generation to generation through culture, associated to the relationship between living beings (including humans) with the surrounding environment. Traditional ecological knowledge is owned collectively and can be conveyed in the form of stories, songs, cultural values, beliefs, rituals, custom laws, local language and natural resource utilization".

The concept of local wisdom in live environment is explained by Berkes (1992) with terminology of traditional ecology science. "The term means a group of science, practice and the conviction develops through adaptive process that is passed from generation to generation through culture, related to relation between human and environment. Traditional ecology science is owned collectively and can be conveyed in the form of story, song, culture value, belief, ritual, custom law, local language and natural resources function".

\section{Values in Local Wisdom}

Local wisdom can be internalization ineducation because of having advantage. The advantage according to Mulyani (2011) as follows: "(1) Local wisdom can be learning medium for all human being to be smart, clever and wise person, (2) Local wisdom has positive values to be transformed to students to form positive personality". Sayuti (2009) proposes that "culture and local potential provides strategic function for character and identity formation. Science about local wisdom has positive side such as: a) having limitation for each individual in interacting to the other individual in one group. For example there is developed value about how to communicate well between parents and young people. b) Detailed characteristic in each local case, so there is no mistake that blames one of individuals. For example there is definite number related to research about life aspect with world line that becomes research object. c) The comparison that may and need between what is developing and background it, so we can deepen special thing of both". The 
conclusion of positive and negative side on each local wisdom science that local wisdom science is substance, owned by someone and will be done right now.

\section{The Method of Providing Basic Local Wisdom}

Based on that case, local wisdom should be part of education because i $t$ can help in forming student's characters and identity. This opinion is supported by Koesoema (2007) that proposes that to applicate characters of education that there are five methods:

1) Teaching integrated values into learning material, so students have conceptual idea about guide of attitude values that can be developed in developing individual characters.

2) Exemplary shown by teacher in Java language means that it is listened and imitated from model prepared by teacher.

3) Deciding the priority that will be effective assessment target during learning.

4) Priority fraction is lifefieldor value that becomes priority in characters of education.

5) Reflection is conducted to know the failure and the success of character education that has been integrated in descriptive text learning.

\section{METHOD}

Type of this research is research and development known as (R\&D), it is local wisdom of Banten material development of for XI grade of Senior High School. This research uses 10 students with small group trial and 30 students with limited field trial. Technique of data collection uses observation, interview, questionnaire, and test.

\section{DISCUSSION}

The result of questionnaire for teachers and students are:

a. One teacher state that she has not known yet how to develop the teaching material or module, most of student felt that they were very confused with the materials or module which used now.

b. All of the teacher's state that they need new module that can me their students are easier to understand the materials. The next step is survey of literature. The students till used the same book for each years. The first beginning product Developments are learning design, content, product revision, and the last conduct of suggestion by student and teacher. In the beginning product, the researcher has taught using module that has made for XI grade as follows:

1. Preference

2. Content

3. Introduction

4. Learning activities

5. Evaluation

6. Answer keys

7. Glossaries

8. Reference

After that, the researcher tried to develop teaching material (module) with validated material by expert, design team and response form students and also teacher.

\section{The Effectiveness of Teaching Materials}

In this step, the researcher tried to make a draft of module; it aims to know there is any improvement or changing in their score and understanding of learning English. The researcher divided some students become small and large group. The first class as experiment and the second class as control. The researcher gave pre-test for experiment and control class. With the aim is to know that any influence or not for score of the students between experimental and control class. 
Table 1. The Result of Pre-Test

\begin{tabular}{lccc}
\hline \multirow{2}{*}{$\begin{array}{c}\text { Data Source } \\
\text { (Pre-test) }\end{array}$} & \multicolumn{2}{c}{ Score } & Score \\
\cline { 2 - 3 } & Min & Max & \\
\hline Experimental Class & 45 & 60 & 54 \\
\hline Control Class & 40 & 60 & 48.5 \\
\hline
\end{tabular}

Table 2. The Result of Post-Test

\begin{tabular}{lccc}
\hline \multirow{2}{*}{$\begin{array}{c}\text { Data Source } \\
\text { (Post-test) }\end{array}$} & \multicolumn{2}{c}{ Score } & \multirow{2}{*}{ Score } \\
\cline { 2 - 3 } & Min & Max & \\
\hline Experimental Class & 60 & 85 & 81.5 \\
\hline Control Class & 60 & 85 & 63.5 \\
\hline
\end{tabular}

Based on the table above, the researcher concludes that learning by using teaching material or module of local wisdom has increased for their score. The average score for experimental class is 74.5 and the average score for control class is 68 . After getting learning by using local wisdom module, there is any increasing for the score. The average score for experiment class is 57 become 74.5, and for control class is 56.5 and 68. It means that learning using local wisdom module got increasing score for experimental and control class.

\section{CONCLUSION}

After getting learning by using local wisdom module, there is any increasing for the score. The average score for experiment class is 57 become 74.5, and for control class is 56.5 and 68. It means that learning using local wisdom module got increasing score for experimental and control class. Teaching material product in this case is module which raised the theme of local wisdom at SMKN 1 Cinangka has gotten maximum score until $17.5 \%$ for experimental class and $11.5 \%$ for control class. It means that new module that content local wisdom has effective result. So it can be used for other school.

\section{REFERENCES}

Albertus, Doni Koesoema. (2007). Pendidikan Karakter, Strategi Mendidik Anak di Zaman Global, Grasindo, Jakarta.

Asyhar, Rayandra. (2012). Kreatif Mengembangkan Media Pembelajaran. Jakarta: Referensi Jakarta.

Berkes, Fikret. (1993). Traditional Ecological Knowledge in Perspektif. In book of Traditional Ecological Knowledge: Concept and Cases. Edited by Julian T. Inglis. Canadian Museum of Nature. Ottawa.

Dahliani \& Ispurwono. (2015).Local Wisdom in Built Environment in Globalization Era. International Journal of Education and Research Vol. 3 No. 6 June 2015.

Depdiknas. (2002). Teknik Belajar dengan Modul. Jakarta: Dirjen Pendidikan Dasar dan Menengah Hamdani. (2011). Strategi Belajar Mengajar. Bandung: Pustaka Setia.

Kurniasih, Imas dan Sani, Berlin. (2014). Panduan Membuat Bahan Ajar Buku Teks Pelajaran Sesuai Dengan Kurikulum 2013. Surabaya: Kata Pena.

Mulyani, Mimi. (2011). Model Pembelajaran Menulis Berbasis Kearifan Lokal Yang Berorientasi. Pendidikan Karakter Studi Kuasi Eksperimen Pada Siswa SMPN 2 Kleas VII, Windusari, Magelang". Jurnal Pendidikan Pena Vol. 1 No. 1. (http://schoolar.google.co.id/schoola r?hl=en-ID\&oe=utf8 \&safe=image\&gcc=id\&ctznAsia

Parmin. (2012). Pengembangan Modul Pembelajaran IPA Terpadu Berwawasan Sains, Lingkungan, Teknologi dan Masyarakat. Jurnal penelitian pendidikan, Vol. 29 Nomor 2 tahun 2012. 
Prastowo, Andi. (2015). Panduan Kreatif Membuat Bahan Ajar Inovatif. Jogjakarta: Diva Press. Ridwan, N.A. (2007). "Landasan Keilmuan Kearifan Lokal". Jurnal Studi Islam dan BudayaVol.5(1).

Sanjaya, Wina. (2010). Strategi Pembelajaran Berorientasi Standar Proses Pendidikan. Jakarta: Kencana.

Sarwono, Sarlito W. dan Eko A. Meinarno. (2009). Psikologi Sosial. Jakarta: Salemba Humanika. Sayuti, S. A. dkk. (2009). Modul Menulis Fiksi. Yogyakarta: PBSI FBS UNY.

Sibarani, Robert. (2012). KearifanLokal. Jakarta: AsosiasiTradisiLisan (ATL).

Sibarani, Robert. (2012). Kearifan Lokal : Hakikat, Peran dan Metode Tradisi Lisan. Jakarta. Badan Standar Nasional Pendidikan.

Winkel. (2009). Psikologi Pengajaran. Yogyakarta: Media Abadi 